\title{
DETERMINAN KECURANGAN AKUNTANSI DALAM PENGELOLAAN DANA DESA
}

\author{
Abdul Hadi ${ }^{1}$, Ikhsan Budi Raharjo ${ }^{2}$, Wahidahwati ${ }^{3}$
}

1,2,3 STIESIA Surabaya

\begin{tabular}{|c|c|}
\hline INFO ARTIKEL & Abstract \\
\hline $\begin{array}{l}\text { Sejarah Artikel: } \\
\text { Diterima : } 2021 \\
\text { Diperbaiki : } 2021 \\
\text { Disetujui : } 2021 \\
\text { Keywords: } \\
\text { Furthermore, The organizational } \\
\text { commitment, the suitabiity of } \\
\text { compensation, and internal } \\
\text { control accounting fraud in } \\
\text { village funds management. }\end{array}$ & $\begin{array}{l}\text { This study aims to Examine and analyze the factors that influence village } \\
\text { officials' tendency to commit fraud in village funds managenment. This study } \\
\text { used the village apparatus in Lamongan Regency as respondents. It analyzed } \\
\text { one hundred twelve questionnaires for hypothesis testing. In this study, the } \\
\text { independent variables were the effectiveness of internal control, information } \\
\text { asymmetry, organizational commitment, the suitability of compensation, and } \\
\text { individual morality, and fraud as the dependent variable. This study applied } \\
\text { multiple linear regression analysistools for hypothesis testing. The results } \\
\text { indicated that the information asymmetry had a significant positive effect and } \\
\text { negativly impacted accounting fraud in village funds management. } \\
\text { Furthermore, The organizational commitment, the suitabiity of compensation, } \\
\text { and internal control had no effect on accounting fraud in village funds } \\
\text { management. }\end{array}$ \\
\hline & \\
\hline $\begin{array}{l}\text { Kata Kunci: } \\
\text { Asimetri informasi, efektivitas } \\
\text { pengendalian internal, } \\
\text { kesesuaian kompensasi, } \\
\text { komitmen organisasi, } \\
\text { moralitas individu, dan } \\
\text { kecurangan (fraud). } \\
\text { DOI: }\end{array}$ & $\begin{array}{l}\text { Penelitian ini bertujuan untuk mempelajari dan menganalisis faktor- } \\
\text { faktor yang mempengaruhi kecenderungan aparat desa untuk berbuat } \\
\text { curang dalam pengelolaan dana desa. Penelitian ini menggunakan } \\
\text { responden dari perangkat desa di Kabupaten Lamong. Terdapat } 112 \\
\text { kuesioner yang dapat dianalisis untuk menguji hipotesis. Variabel } \\
\text { yang digunakan dalam penelitian ini adalah efektivitas pengendalian } \\
\text { internal, asimetri informasi, komitmen organisasi, kesesuaian } \\
\text { kompensasi dan moralitas individu sebagai variabel bebas dan } \\
\text { kecurangan sebagai variabel terikat. Penelitian ini menggunakan } \\
\text { analisis regresi linier berganda untuk menguji hipotesis. Hasil } \\
\text { penelitian ini membuktikan bahwa asimetri informasi berpengaruh } \\
\text { positif signifikan dan moralitas individu berpengaruh negatif } \\
\text { signifikan terhadap kecurangan akuntansi dalam pengelolaan dana } \\
\text { pedesaan. Komitmen organisasi, kesesuaian kompensasi dan } \\
\text { pengendalian internal tidak mempengaruhi kecurangan akuntansi } \\
\text { dalam pengelolaan dana pedesaan. }\end{array}$ \\
\hline $\begin{array}{l}\text { Korespondensi: } \\
\text { Nama: Abdul Hadi } \\
\text { Email:abdulhadihadi261@gmail.com }\end{array}$ & $\begin{array}{l}\text { ISSN: 2355-9643 (print) } \\
\text { ISSN: 2460-3775 (online) }\end{array}$ \\
\hline
\end{tabular}




\section{PENDAHULUAN}

Dampak logis dari munculnya konsep otonomi daerah adalah adanya desentralisasi fiskal. Pelaksanaan desentralisasi fiskal pada era reformasi secara resmi dimulai pada tanggal 1 Januari 2001. Proses ini dimulai dengan disahkannya Undang-Undang Nomor 22 Tahun 1999 tentang Pemerintahan Daerah dan UndangUndang Nomor 25 Tahun 1999 tentang Perimbangan Keuangan antara Pemerintah Pusat dan Daerah (PKPD). ). Sampai saat ini, kedua keputusan tersebut telah mengalami beberapa kali perubahan, yang terakhir adalah Undang-Undang Nomor 23 Tahun 2014 tentang Pemerintahan Daerah dan Undang-Undang Nomor 33 Tahun 2004 tentang Perimbangan Keuangan antara Pemerintah Pusat dan Pemerintah Daerah. Begitu pula dengan Undang-Undang Nomor 6 Tahun 2014 tentang Desa memancing kontroversi di masyarakat, serta membuat beberapa ketidaksetujuan di sebagian masyarakat.

Sejak 2015, pemerintah telah mendistribusikan APBN ke desa atau biasa disebut dana desa. Undang-Undang Nomor 6 Tahun 2014. Alokasi pendanaan daerah terus meningkat hingga tahun 2017, namun dibatalkan pada tahun 2018 karena beberapa masalah. Hampir semua mata tertuju di desa. Dimulai dengan para pejabat, ilmuwan, politisi, pengamat, dan aktivis LSM yang ingin mendalami desa tersebut. Mereka ingin melihat dinamika pembangunan pedesaan saat ini, mengingat adanya Undang-Undang Nomor 6 Tahun 2014 di pedesaan. Sebagian besar perhatian pihak desa hanya merupakan hasil pendanaan desa, yang jumlahnya telah ditingkatkan oleh pemerintah (pusat). Hal ini menunjukkan bahwa pembangunan desa dilakukan secara serius oleh pemerintah dan bukti bahwa janji politik Jokowi-JK telah terpenuhi selama kampanye pemilihan presiden 2014. Menurut Doller \& Wallis (2001), distribusi dana desa memegang peranan penting dan merupakan kunci keberhasilan otonomi daerah. Kurun waktu 2015 - 2019, suntikan anggaran yang cukup besar ke desa-desa dengan alokasi dasar Rp 616.345 hingga 1 miliar, direalisasikan Rp 256,9 triliun. Peningkatan dana diharapkan dapat memajukan desa. Pemerintah menginginkan agar pelayanan bersama desa meningkat, masyarakat desa dibina, diberdayakan, dan yang terpenting desa menjadi sasaran pembangunan. Tentu saja, peran besar yang dimainkan desa membawa banyak tanggung jawab. Efisiensi dan efektivitas alokasi dana daerah
(ADD) dari pemerintah daerah / pemerintah kota kepada pemerintah daerah dan cara penggunaannya sangat penting karena merupakan parameter paling sederhana untuk keberhasilan sentralisasi (Ahmad Erani Yustika, 2008).

Layanan Manajemen Korupsi Indonesia (ICW) menilai korupsi di desa menjadi salah satu masalah mendasar, terutama terkait dengan anggaran desa. Masalah ini muncul dari pengelolaan anggaran yang besar, namun pelaksanaannya di tingkat desa tidak melibatkan prinsip transparansi, partisipasi, dan akuntabilitas dalam penyelenggaraan politik, pembangunan, dan keuangan desa. Di tahun 2018, tahun Pilkada 2018 dan Pilkada Serentak 2019, muncul kekhawatiran akan berbagai penyalahgunaan APBD. Kekhawatiran ini tidak semata-mata karena fenomena korupsi Rusia selama tiga tahun terakhir. Desa. Namun, perhatian publik dan media nasional terhadap desa tertuju pada fenomena bahwa kepala desa terkait dengan calon kepala daerah tertentu, terutama terkait dengan posisi strategis desa dalam rangka kemenangan pilkada yang masih terdapat kekurangan. Kurangnya pengetahuan dan pengawasan masyarakat pedesaan. Koruptor desa menggunakan berbagai cara, antara lain 51 penyalahgunaan anggaran, 32 penggelapan, 17 laporan fiktif, 15 kegiatan / proyek fiktif, dan 14 penggelembungan anggaran. Dan banyak masalah terkait pengawasan dana lokal yang masih ditemukan. Berdasarkan review Direksi atas Laporan Keuangan Pemerintah Pusat (LKPP) 2017, BPK menemukan bahwa tidak ada sistem pengawasan untuk pengelolaan dana daerah.

Kementerian Dalam Negeri belum mengembangkan sistem pemantauan pengelolaan uang daerah, tidak ada aplikasi untuk memantau pengelolaan uang daerah, dan standar akuntansi yang belum ditetapkan oleh pemerintah daerah. Pemerintah tidak mempertimbangkan perencanaan pembangunan pedesaan atau memprioritaskan penggunaan dana desa, dan BUMDes tidak dapat memberikan kontribusi yang signifikan bagi perekonomian pedesaan. Minimnya penyaluran dana daerah dari pemerintah daerah diperparah dengan banyaknya masyarakat baik desa maupun kabupaten yang menggunakan ADD tanpa hak dan kewenangan. Tentunya, potensi penyelewengan dana dari desa sangat tinggi, hal ini tidak terlepas dari lemahnya pengawasan aparat pemerintah daerah. Selain itu, aparat administrasi desa yang umumnya lemah itu sendiri juga kurang penting. 
Berbagai fenomena tersebut disebabkan oleh kecurangan dalam pengelolaan dana desa. Salah satunya adalah kecurangan akuntansi. kecurangan yang sering terjadi termasuk memanipulasi catatan, menghapus dokumen, dan markup yang merusak keuangan dan ekonomi suatu negara. Menurut Association of Certified Fraud Examiners (ACFE), kecurangan akuntansi dapat dibagi menjadi tiga jenis: penyalahgunaan aset, klaim penipuan, dan korupsi.

Sebuah studi oleh Nurul et al. (2017) menunjukkan bahwa asimetri informasi berpengaruh positif dan signifikan terhadap kecurangan akuntansi. Kepatuhan akuntansi dan komitmen organisasi memiliki pengaruh negatif yang signifikan terhadap kecurangan akuntansi. Pengendalian internal berperan dalam membatasi kepatuhan akuntansi terhadap kecurangan akuntansi (moderasi asli), tetapi asimetri informasi dan komitmen organisasi hanya memperlemah hubungan (moderasi homologasi). Selain itu, kecurangan akuntansi dan dampak negatifnya yang serius terhadap pelaporan keuangan. Selain itu, pentingnya penelitian ini menitikberatkan pada efektivitas penerapan sistem pengendalian intern khususnya penerapan sistem pengendalian intern di bidang kesehatan yang dapat menjadi alat untuk prediksi dan deteksi dini. (Dibangun ke dalam sistem pemeriksaan). ) Inkonsistensi atau perbedaan yang diakibatkan oleh kesalahan FKTP. / Pusat kesehatan. Penelitian Admaji dan Saputra (2017) menunjukkan bahwa kapabilitas perangkat berpengaruh terhadap pencegahan kecurangan dalam pengelolaan keuangan daerah. Sistem pengendalian internal mempengaruhi pencegahan kecurangan dalam pengelolaan keuangan desa. Moralitas telah berhasil memitigasi dampak peralatan dan sistem pengendalian internal terhadap pencegahan kecurangan dalam pengelolaan keuangan desa.

Banyak faktor yang dapat mempengaruhi kecurangan akuntansi pemerintahan. Beberapa di antaranya termasuk efektivitas pengendalian internal, penerimaan penghargaan, asimetri informasi, budaya etika organisasi, dan komitmen organisasi. Penelitian ini berbeda dengan penelitian sebelumnya yaitu menggabungkan variabel dari beberapa penelitian, dan tujuan penelitian juga berbeda. Artinya, kecurangan akuntansi yang terjadi dalam pengelolaan dana desa, topik penelitian dan penelitian yang lebih relevan. Kepada perangkat desa. Manajer keuangan lokal. Berdasarkan uraian di atas, penelitian ini berjudul "Determinan kecurangan akuntansi dalam pengelolaan dana desa". Berdasarkan uraian di atas, Berdasarkan rumusan masalah yang diajukan, tujuan dari penelitian ini adalah untuk: ((1) Menguji dan menganalisis pengaruh efektivitas pengendalian internal berpengaruh teradap kecurangan akuntansi dalam pengelolaan dana desa, (2) Menguji dan menganalisis pengaruh asimetri informasi berpengaruh teradap kecurangan akuntansi dalam pengelolaan dana desa, (3) Menguji dan menganalisis pengaruh komitmen organisasi berpengaruh teradap kecurangan akuntansi dalam pengelolaan dana desa, (4) Menguji dan menganalisis pengaruh kesesuaian kompensasi berpengaruh teradap kecurangan akuntansi dalam pengelolaan dana desa, dan (5) Menguji dan menganalisis pengaruh moralitas individu berpengaruh teradap kecurangan akuntansi dalam pengelolaan dana desa.

\section{METODE \\ Jenis dan Teknik Pengumpulan data}

Penelitian ini merupakan penelitian kuantitatif dimana data yang digunakan adalah data utama. Pendekatan kuantitatif menurut Azwar (2008: 5) merupakan studi yang difokuskan pada analisis data numerik yang diolah dengan metode statistik tertentu. Dengan kata lain, jika data yang digunakan adalah numerik, survei menggunakan pendekatan kuantitatif untuk mensurvei populasi atau sampel tertentu, mengumpulkan data dan alat survei, serta menulis dan menguji hipotesis yang telah ditetapkan. Penelitian ini terdiri dari lima variabel yaitu efektivitas pengendalian internal (EP), asimetri informasi (AI), komitmen organisasi (KO), kepatuhan kompetensi (KK), dan moralitas pribadi (MI). Survei yang dilakukan di wilayah Ramongan ini menargetkan populasinya, yaitu semua desa di wilayah Lamongan.

Salah satu keberhasilan atau kegagalan suatu penelitian adalah metode pengumpulan data. Metode diperlukan dalam pengumpulan data digunakan, sehingga data yang diambil sesuai dengan yang diharapkan. Metode pengumpulan data untuk penelitian ini menggunakan kuesioner. kuesioner tersebut diadopsi dari kuesioner yang dilakukan oleh Firdaus (2018) yang berjudul "Analisis Faktor-faktor yang Mempengaruhi Kecenderungan Karyawan Melakukan Fraud Sektor Publik" dan Janita Maya (2015) tentang Faktor-Faktor yang Mempengaruhi Fraud Sektor pemerintahan. 


\section{Populasi dan Sampel}

Populasi adalah suatu wilayah generalisasi yang terdiri dari objek atau subjek dengan sifat dan karakteristik tertentu yang ditetapkan peneliti untuk penelitiannya dan kesimpulan selanjutnya (Sugiyono, 2010: 117). Populasi survei ini adalah seluruh kepala desa, sekretaris, bendahara desa atau perangkat desa di Kabupaten Lamongan, dan menurut BPS Kabupaten Lamongan jumlah desa adalah 462 desa. Jika tiga responden memilih satu desa, jumlah polpulasi 1386 responden.

Menurut Sugiyono (2017: 81), sampel merupakan bagian dari ukuran dan karakteristik populasi. Pengambilan sampel dilakukan karena peneliti memiliki keterbatasan baik waktu, tenaga, uang, maupun populasi yang sangat besar. Menggunakan persamaan yang dikemukakan oleh Slovin dalam Mustafa (2010: 90), untuk menentukan ukuran sampel diambil dari populasi penelitian dengan nilai $\mathrm{e}=10 \%$ dan tingkat kepercayaan $90 \%$ sebagai berikut.

Rumus : $n=\frac{\mathbb{N}}{1+N e^{2}}$

Dimana :

$\mathrm{n}=$ Jumlah Sampel

N= Jumlah Populasi

$\mathrm{e}=$ Tingkat kesalahan dalam memilih anggota sampel yang ditolelir sebesar $10 \%$ sampel yang masih dapat ditolerir atau diinginkan sebanyak 10 $\%$.

$n=\frac{1386}{1+1386(0,1)^{2}}=93,270 \approx 100$

\section{Variabel Operasional dan Pengukuran Variabel}

Penelitian ini menggunakan dua jenis variabel yaitu variabel terikat (variabel terikat) dan variabel bebas (variabel bebas). Variabel terikat dalam penelitian ini adalah kecurangan akuntansi dalam pengelolaan dana daerah. Variabel independen (variabel penjelas), di sisi lain, adalah faktor-faktor yang mempengaruhi kecurangan akuntansi, seperti efektivitas pengendalian internal, asimetri informasi, komitmen organisasi, penerimaan penghargaan, dan moralitas pribadi.

Dalam penelitian ini variabel dependennya adalah kecurangan akuntansi. Pengukuran variabel ini terdiri dari sembilan pertanyaan yang dirancang seputar jenis kecurangan, antara lain laporan keuangan yang mengandung kecurangan, penyalahgunaan aset, dan korupsi, menurut Association of Certified Fraud Examiners (ACFE) dalam Rudianto (2012). Saat mengukur variabel ini dengan menggunakan Skala Likert 1, 5 merupakan kecocokan yang sangat baik, dan semakin tinggi nilai yang ditampilkan maka semakin tinggi pula kejadian penipuan. Variabel Fraud diukur dengan indikator dari survei Firdaus (2017) sebagai berikut: (1) pelaporan keuangan yang mengandung kecurangan, (2) penyalahgunaan aset, dan (3) korupsi.

Variabel independen merupakan variabel yang mempengaruhi variabel terikat, dan dalam penelitian variabel bebas adalah asimetri informasi, penegakan hukum, kesesuaian kompensasi, dan moralitas pribadi. Diukur menggunakan kuesioner pada skala likert dari 1 sampai 5. Yaitu, (1), Tidak Setuju (2), Netral (3), Setuju (4), Sangat Tidak Setuju (5).

\section{ANALISIS DATA Hasil Uji Statistik Deskriptif}

\begin{tabular}{|l|l|r|r|r|r|r|r|}
\hline \multicolumn{2}{|c|}{} & TOTAL.F & TOTAL.Al & TOTAL.KO & TOTAL.KK & TOTAL.MI & TOTAL.PI \\
\hline \multirow{2}{*}{$\mathrm{N}$} & Valid & 112 & 112 & 112 & 112 & 112 & 112 \\
\cline { 2 - 8 } & Missing & 0 & 0 & 0 & 0 & 0 & 0 \\
\hline \multirow{2}{*}{ Mean } & 15,5357 & 15,8839 & 20,8393 & 31,7768 & 18,9464 & 20,3839 \\
\hline Std. Deviation & 3,75830 & 5,22079 & 2,76253 & 3,80542 & 3,37409 & 1,94633 \\
\hline Minimum & 8,00 & 6,00 & 10,00 & 14,00 & 9,00 & 14,00 \\
\hline Maximum & 26,00 & 30,00 & 25,00 & 40,00 & 31,00 & 25,00 \\
\hline
\end{tabular}

Sumber: Hasil Olah Data SPSS

Berdasarkan survei responden terhadap variabel kecurangan akuntansi, jumlah pertanyaan yang dijawab oleh responden minimal 8 , dan jumlah pertanyaan yang dijawab oleh responden maksimal 26. Kecurangan variabel nilai rata-rata aktual tren adalah 15. 53. Sedangkan standar deviasi menunjukkan bahwa dari 112 responden yang disurvei, besarnya variabilitas variabel kecurangan adalah 3,75. Standar deviasi 3,75 lebih kecil dari rata-rata 15,53, menunjukkan bahwa varians data dianggap kecil.

Berdasarkan survei responden terhadap variabel asimetri informasi, jumlah pertanyaan yang dijawab oleh responden minimal 6, dan jumlah maksimal pertanyaan yang dijawab oleh responden adalah 30. Rerata aktual variabel asimetri informasi adalah 15,88. Simpangan baku menunjukkan bahwa sebaran variabel informasi asimetris adalah 5,22 dari 112 responden yang disurvei. Standar deviasi 5.22 lebih kecil dari ratarata 15,88 yang menunjukkan bahwa data deviasi tergolong kecil. 
Survei responden terhadap variabel komitmen organisasi menunjukkan bahwa jumlah pertanyaan yang dijawab oleh responden minimal 10, dan jumlah pertanyaan yang dijawab oleh responden maksimal adalah 25 . Rata-rata variabel komitmen organisasi yang sebenarnya adalah 11,80. Simpangan baku menunjukkan bahwa besarnya sebaran variabel komitmen organisasi adalah 2,76 dari 112 responden yang disurvei. Standar deviasi 2,76 rata-rata kurang dari 20, menunjukkan bahwa deviasi data dianggap kecil.

Survei responden terhadap variabel kesesuaian kompensasi menunjukkan bahwa jumlah pertanyaan yang dijawab oleh responden minimum adalah 14 , dan jumlah pertanyaan yang dijawab oleh responden maksimum adalah 40 . Rata-rata variabel kesesuaian kompensasi adalah 31.77. Standar deviasi menunjukkan besarnya sebaran variabel kesesuaian kompensasi adalah 3,80 dari 112 responden yang disurvei. Simpangan baku 3,80 lebih kecil dari rata-rata 31,77 yang menunjukkan bahwa penyimpangan data tergolong kecil.

Hasil survei responden terhadap variabel moralitas individu menunjukkan bahwa jumlah pertanyaan yang dijawab oleh responden minimal 9, dan jumlah pertanyaan yang dijawab oleh responden maksimal 31. Rata-rata aktual variabel moralitasindividu adalah 18,94. Standar deviasi menunjukkan bahwa luas penyebaran variabel moral individu adalah 3,37 dari 112 responden yang disurvei. Simpangan baku 3,37 lebih kecil dari rata-rata 18,94 yang menunjukkan bahwa penyimpangan data tergolong kecil.

Berdasarkan survei responden terhadap variabel pengendalian internal, jumlah pertanyaan yang dijawab oleh responden minimum adalah 14, dan jumlah pertanyaan yang dijawab oleh responden maksimum adalah 25 . Rata-rata variabel moral individu yang sebenarnya adalah 20,38. Standar deviasi menunjukkan bahwa luas penyebaran variabel pengendalian internal adalah 1,94 dari 112 responden yang disurvei. Standar deviasi 1,94 lebih kecil dari rata-rata 20,38 yang menunjukkan bahwa deviasi data tergolong kecil.

Hasil Uji Regresi Linier Berganda

\begin{tabular}{|c|c|c|c|c|c|c|c|c|c|c|}
\hline \multicolumn{11}{|c|}{ Coefficients $^{8}$} \\
\hline \multirow[t]{2}{*}{ Model } & \multicolumn{2}{|c|}{$\begin{array}{l}\text { Unstandardized } \\
\text { Coefficients }\end{array}$} & \multirow{2}{*}{$\begin{array}{c}\begin{array}{c}\text { Standardized } \\
\text { Coefficients }\end{array} \\
\text { Beta } \\
\end{array}$} & \multirow[t]{2}{*}{$t$} & \multirow[t]{2}{*}{ Sig. } & \multicolumn{3}{|c|}{ Correlations } & \multicolumn{2}{|c|}{ Collinearity Statistics } \\
\hline & $B$ & Std. Error & & & & Zero-order & Partial & Part & Tolerance & $\mathrm{VIF}$ \\
\hline (Constant) & 8.523 & 4.035 & & 2.112 & .037 & & & & & \\
\hline TOTALAI & .181 & .070 & .252 & 2.605 & .011 & .422 & 245 & 212 & .708 & 1.411 \\
\hline TOTAL.KO & -158 & .118 & -116 & -1.336 & .185 & -106 & -129 & -109 & .874 & 1.144 \\
\hline${ }^{1}$ TOTAL.KK & .001 & .094 & .001 & .012 & .990 & -.033 & .001 & .001 & .735 & 1.360 \\
\hline TOTAL.MI & .410 & .107 & .368 & 3.850 & .000 & .488 & 350 & 313 & .724 & 1.382 \\
\hline TOTAL.PI & .019 & .173 & .010 & -107 & .915 & -.021 & -.010 & .009 & .829 & 1.206 \\
\hline
\end{tabular}

a. Dependent Variable: TOTALF
Model persamaan regresi yang di gunakan adalah sebagai berikut

$\mathrm{F}=8.523+0,181 \mathrm{AI}-0,152 \mathrm{KO}+0,001 \mathrm{KK}+0,410$

MI - 0,019 PI

Di mana:

$\mathrm{F} \quad=$ Fraud

AI $=$ Asimetri Informasi

$\mathrm{KO}=$ Komitmen Organisasi

KK = Kesesuaian Kompensasi

MI = Moralitas Individu

PI = Pengendalian Internal

\section{Hasil Uji Multikolinieniritas}

\begin{tabular}{|c|c|c|}
\multicolumn{3}{|c|}{ Hasil Uji Multikolinieritas } \\
\hline \multirow{2}{*}{ Model } & \multicolumn{2}{|c|}{ Collinearity statistics } \\
\cline { 2 - 3 } & Tolerance & VIF \\
\hline AI & 0,708 & 1.411 \\
\hline KO & 0,874 & 1.144 \\
\hline KK & 0,735 & 1.360 \\
\hline MI & 0.724 & 1.382 \\
\hline PI & 0,829 & 1.206 \\
\hline
\end{tabular}

Sumber : Hasil olah data primer, 2020

Berdasarkan tabel menunjukkan bahwa nilai tolerance dari kelima variabel independen nilai tolerencenya kurang dari 0.10 dan nilai VIF lebih dari 10. Oleh karena itu dapat disimpulkan bahwa dalam model regresi tersebut terbebas dari masalah multikolinearitas, sehingga layak untuk digunakan.

\section{Hasil Uji Heteroskedastitas}

\begin{tabular}{|l|r|}
\hline \multicolumn{2}{|c|}{ Masil Uji Heteroskedastisitas } \\
\hline Fraud (F) & Nilai Signifikansi \\
\hline Asimetri Informasi (AI) &, 355 \\
\hline Moralitas Individu (MI) &, 422 \\
\hline Pengendalian Internal &, 598 \\
\hline Komitmen Organisas (KO) &, 341 \\
\hline Kesesuaian Kompetensi (KK) &, 560 \\
\hline Sumber : Hasil olah data primer, 2020 &
\end{tabular}

Berdasarkan tabel di atas dapat dilihat bahwa variabel kecurangan, komitmen organisasi, moralitas pribadi, pengendalian internal, dan kesesuaian ganti rugi mempunyai nilai signifikan lebih besar dari 0,05. Artinya bisa digunakan. Sedangkan nilai signifikansi variabel asimetri informasi adalah 0,008. Artinya variabel ini memiliki masalah distribusi yang tidak seragam. Hal ini dapat terjadi karena terdapat perbedaan / kerentanan yang besar antara nilai minimum dan maksimum. 
Hasil uji Normalitas

\begin{tabular}{|c|c|c|}
\hline \multicolumn{3}{|c|}{ Hasil Uji Normalitas } \\
\hline \multicolumn{3}{|c|}{ One-Sample Kolmogorov-Smirnov Test } \\
\hline & & $\begin{array}{c}\text { Unstandardized } \\
\text { Residual }\end{array}$ \\
\hline \multicolumn{2}{|l|}{$\mathrm{N}$} & 112 \\
\hline \multirow{2}{*}{ Normal Parameters ${ }^{a, b}$} & Mean & $O E-7$ \\
\hline & Std. Deviation & 3,14778379 \\
\hline \multirow{3}{*}{ Most Extreme Differences } & Absolute &, 082 \\
\hline & Positive & .082 \\
\hline & Negative & -.053 \\
\hline \multicolumn{2}{|l|}{ Kolmogorov-Smirnov $Z$} & .865 \\
\hline \multicolumn{2}{|l|}{ Asymp. Sig. (2-tailed) } & .443 \\
\hline \multicolumn{3}{|l|}{ a. Test distribution is Normal. } \\
\hline \multicolumn{3}{|l|}{ b. Calculated from data. } \\
\hline
\end{tabular}

Bahwa Asymp. 0.433 Sig (kedua sisi). Karena hasil ini lebih besar dari 0,05, maka dapat disimpulkan bahwa data residual untuk model regresi ini berdistribusi normal. Oleh karena itu, model regresi dalam penelitian ini layak digunakan dalam penelitian.

Hasil Koeefisien Determinan Hasil Uji Koefisien Determinan Model Summary b

\begin{tabular}{|c|c|c|c|c|c|c|c|c|c|c|}
\hline \multicolumn{11}{|c|}{ Model Summaryb } \\
\hline \multirow[t]{2}{*}{ Model } & \multirow[t]{2}{*}{$\mathrm{R}$} & \multirow{2}{*}{$\begin{array}{c}\mathrm{R} \\
\text { Square }\end{array}$} & \multirow{2}{*}{$\begin{array}{l}\text { Adjusted R } \\
\text { Square }\end{array}$} & \multirow{2}{*}{$\begin{array}{l}\text { Std. Error of } \\
\text { the Estimate }\end{array}$} & \multicolumn{5}{|c|}{ Change Statistics } & \multirow{2}{*}{$\begin{array}{l}\text { Durbin- } \\
\text { Watson }\end{array}$} \\
\hline & & & & & $\begin{array}{c}\text { R Square } \\
\text { Change }\end{array}$ & F Change & df1 & $\mathrm{d} f 2$ & \begin{tabular}{|c|} 
Sig. F \\
Change
\end{tabular} & \\
\hline 1 & $.546^{\mathrm{a}}$ & .299 & .265 & 3.22117 & .299 & 9.021 & 5 & 106 & .000 & 1.376 \\
\hline \multicolumn{11}{|c|}{ a. Predictors: (Constant), TOTAL.PI, TOTAL.AI, TOTAL.KO, TOTAL.KK, TOTAL.MI } \\
\hline b. Dep & $\pm \sqrt{ } a$ & le: TOT & & & & & & & & \\
\hline
\end{tabular}

Berdasarkan data pada Tabel 12, diketahui hasil uji koefisien determinan menghasilkan nilai adjusted r-squared sebesar 0,299. Hasil tersebut dapat disimpulkan bahwa variasi variabel independen dalam mempengaruhi atau menjelaskan variabel dependen adalah sebesar 0,299 atau 29,9\%. Sebanyak $70,1 \%$ sisanya dipengaruhi oleh variabel lain yang tidak dimasukkan dalam penelitian ini. Hasil Uji F

\begin{tabular}{|c|c|c|c|c|c|c|}
\hline \multicolumn{7}{|c|}{ Hasil Uji F } \\
\hline \multicolumn{7}{|c|}{ ANOVAa } \\
\hline \multicolumn{2}{|c|}{ Model } & Sum of & df & Mean & & Sig. \\
\hline \multirow{3}{*}{1} & Regression & 468.009 & 5 & 93.602 & 9.021 & $.000^{\mathrm{b}}$ \\
\hline & Residual & 1099.848 & 106 & 10.376 & & \\
\hline & Total & 1567.857 & 111 & & & \\
\hline \multicolumn{7}{|c|}{ a. Dependent Variable: TOTAL.F } \\
\hline \multicolumn{7}{|c|}{$\begin{array}{l}\text { b. Predictors: (Constant), TOTAL.PI, TOTAL.AI, TOTAL.KO, TOTAL.KK, } \\
\text { TOTAL.MI }\end{array}$} \\
\hline
\end{tabular}

Berdasarkan hasil uji F (signifikansi 0,000) lebih kecil dari taraf signifikansi $a=5 \%$. Oleh karena itu, variasi nilai variabel independen atau variabel independen dapat menjelaskan variasi nilai dependen. Akibatnya, asimetri informasi, komitmen organisasi, kesesuaian penghargaan, moralitas pribadi, dan variabel pengendalian internal secara bersama-sama (simultan) dikoordinasikan sehubungan dengan tren kecurangan.

\section{Hasil Uji t}

Uji $\mathrm{t}$ digunakan untuk mengetahui apakah variabel independen mempengaruhi variabel dependen secara individual. Pada prosedur uji probabilitas statistik $t$ atau nilai $p$ kita hanya membandingkan nilai probabilitas $\mathrm{p}$ dengan nilai signifikansi a yang kita pilih. . Dalam penelitian ini menggunakan a sebesar 5\%, yaitu dengan membandingkan $p$-value. Kriteria penerimaan atau penolakan hipotesis sebagai berikut :

1. Apabila $p$-value $>5 \%$, maka hipotesis ditolak yang berarti variabel independen tidak berpengaruh terhadap variabel dependen.

2. Apabila $p$-value $<5 \%$, maka hipotesis diterima yang berarti variabel independen berpengaruh terhadap variabel dependen.

Berdasarkan uji F dapat di simpulkan bahwa,

1. Variabel-variabel independen (Asimetri Informasi, Penegakan Hukum, Kesesuaian Kompensasi, dan Moralitas Individu diasumsikan tidak mengalami perubahan (konstan) maka nilai Kecenderungan Fraud adalah sebesar 8.523.

2. Koefisien uji $\mathrm{t}$ asimetri informasi adalah 0.181, nilai signifikansinya adalah 0.011, dan $\mathrm{t}$ hitungnya adalah 2.605. Dari hasil tersebut dapat di ketahui nilai signifikansi nya sebesar 0.011 yang berarti lebih kecil daripada 0.05 , dan $\mathrm{t}$ hitung di ketahui sebesar 2.605 yang berarti lebih besar dari $t$ tabel sebesar 1.982. Hal ini dapat diartikan bahwa asimetri informasi berpengaruh positif signifikan terhadap fraud. Sehingga hipotesis pertama diterima.

3. Koefisien uji $t$ komitmen organisasi adalah 0,158 , nilai signifikansinya adalah 0,185 , dan $t$ hitungnya adalah -1336. Dari hasil tersebut dapat diketahui nilai signifikansi nya sebesar 0,185 yang berarti lebih besar darip 0.05 , dan $\mathrm{t}$ hitungnya di ketahui sebesar -1336 yang berarti lebih kecil dari $t$ tabel sebesar 1.979. Hal ini dapat diartikan bahwa komitmen organisasi tidak berpengaruh terhadap kecenderungan fraud. Sehingga hipotesis kedua ditolak.

4. Koefisien uji $\mathrm{t}$ kesesuaian kompensasi adalah 0.01 , nilai signifikansinya adalah 0.990 , dan $\mathrm{t}$ hitungnya adalah 0,012. Dari hasil tersebut diketahui nilai signifikansinya sebesar 0.990 yang berarti lebih lebih besar dari 0.05 , dan $t$ hitungnya diketahui sebesar 0,012 yang berarti lebih kecil dari t tabel sebesar 1.979. hal ini dapat diartikan bahwa kesesuaian kompensasi tidak berpengaruh terhadap 
kecenderungan fraud. Sehingga hipotesis ketiga ditolak.

5. Koefisien uji $\mathrm{t}$ moralitas individu adalah -0.410 , nilai signifikansinya adalah 0.000 , dan $t$ hitungnya adalah 3850. Dari hasil tersebut diketahui nilai signifikansinya sebesar 0.000 yang berarti lebih kecil dari 0.05, dan $t$ hitungnya diketahui sebesar 5.232 yang berarti lebih besar dari $t$ tabel sebesar 1.979. Hal ini dapat diartikan bahwa moralitas individu berpengaruh negatif signifikan terhadap kecenderungan fraud. Sehingga hipotesis keempat diterima

6. Koefisien uji $\mathrm{t}$ pengendalian internal adalah 0.19 , nilai signifikansinya adalah 0,915 , dan $t$ hitungnya adalah -0,107. Dari hasil tersebut diketahui nilai signifikansinya sebesar 0,915 yang berarti lebih kecil dari 0.05, dan $t$ hitungnya diketahui sebesar -0,107 yang berarti lebih kecil dari $t$ tabel sebesar 1.979. Hal ini dapat diartikan bahwa moralitas individu tidak berpengaruh negatif signifikan terhadap kecenderungan fraud. Sehingga hipotesis keempat ditolak

\section{Hasil dan Pembahasan}

1. Pengaruh Asimetri Informasi Terhadap Kecurangan Akuntansi.

Koefisien uji regresi asimetri informasi adalah 0.181, nilai signifikansinya adalah 0.011 . Seperti yang sudah diujikan dengan menggunakan uji $t$, hasil penelitian menunjukan bahwa asimetri informasi berpengaruh positif signifikan terhadap kecurangan akuntasi dalam pengeloaan dana desa. Kondisi semacam itu tentu saja dapat membuka peluang bagi perangkat pemerintah desa untuk melakukan kecurangan dengan menyajikan informasi keuangan yang tidak sesuai dengan kondisi yang sebenarnya. Tujuannya semata-mata hanya karena ingin mendapatkan penilaian yang baik atas kinerja yang telah dilakukan dengan memanipulasi informasi keuangan. Dengan kata lain asimetri informasi merupakan kondisi dimana adanya ketidakselarasan informasi yang di terima antara pihak yang menyediakan informasi atau yang memiliki informasi dengan pihak yang menerima atau membutuhkan informasi untuk proses pengambilan keputusan.

2. Pengaruh Komitmen Organisasi Terhadap Kecurangan Akuntansi.

Pengujian dilakukan melalui signifikansi koefisien regresi komitmen organisasi. komitmen organisasi memiliki nilai koefisien negatif sebesar $-0,158$, nilai signifikansinya adalah 0,185. Seperti yang sudah diujikan dengan menggunakan uji regresi, hasil penelitian menunjukan bahwa komitmen organisasi tidak berpengaruh terhadap kecurangan akuntansi. Hasil penelitian ini menunjukan bahwa komitmen organisasi pada suatu pemerintahan desa tidak akan mempengaruhi seseorang untuk melakukan kecurangan (fraud) akuntansi dalam pengelolaan dana desa. Menurut teori fraud triangle, salah satu aspek dalam teori ini adalah kesempatan. Menurut Pravitasari, (2016) kesempatan adalah situasi terbukanya kesempatan bagi pegawai yang memungkinkan untuk terjadinya tindak kecurangan. Adanya kesempatan atau peluang tersebut karena pengendalian internalnya lemah, pengawasan yang kurang baik, serta lemahnya penegakan hukum di instansi tersebut.

3. Pengaruh Pengendalian Internal Terhadap Kecurangan Akuntansi

Pengujian dilakukan melalui signifikansi koefisien regresi variabel penegakan hukum. Penegakan hukum memiliki nilai koefisien 0.19 , nilai signifikansinya adalah 0,915 . Seperti yang sudah diujikan dengan menggunakan uji regresi, hasil penelitian menunjukan bahwa pengendalian internal tidak berpengaruh terhadap kecurangan akuntansi dalam pengelolaan dana desa. Hasil penelitian ini menunjukan bahwa tegak atau tidaknya pengendalian internal tidak akan mempengaruhi seseorang untuk melakukan kecurangan (fraud). Menurut teori fraud triangle, salah satu aspek dalam teori ini adalah kesempatan. Menurut Pravitasari (2016) kesempatan adalah situasi terbukanya kesempatan bagi pegawai yang memungkinkan untuk terjadinya tindak kecurangan. Adanya kesempatan atau peluang tersebut karena pengendalian internalnya lemah, pengawasan yang kurang baik, serta lemahnya penegakan hukum di instansi tersebut.

4. Pengaruh Kesesuaian Kompensasi Terhadap Kecurangan Akuntansi

Pengujian dilakukan melalui signifikansi regresi variabel kesesuaian kompensasi. Kesesuaian kompensasi memiliki nilai 0.01, nilai signifikansinya adalah 0.990 . Seperti yang sudah diujikan dengan menggunakan uji regresi, hasil penelitian ini menunjukan bahwa 
kesesuaian kompensasi tidak berpengaruh kecurangan dalam pengelolaan dana desa. Hasil penelitian ini sejalan dengan penelitian yang sudah dilakukan oleh Firdaus (2017) yang menyatakan bahwa kesesuaian kompensasi tidak berpengaruh terhadap kecenderungan pegawai untuk melakukan sebuah kecurangan. Namun penelitian ini juga berbanding terbalik dengan penelitian yang dilakukan oleh Softian (2017), Dewi (2017), dan Pravitasari (2016).

5. Pengaruh Moralitas Individu Terhadap Kecurangan Akuntansi.

Pengujian dilakukan melalui signifikansi regresi variabel moralitas individu. Moralitas individu memiliki nilai koefisien negatif -0.410 , nilai signifikansinya adalah 0.000 . Seperti yang sudah diujikan dengan menggunakan uji regresi, hasil penelitian ini menunjukan bahwa moralitas individu berpengaruh negatif signifikan terhadap kecurangan akuntansi dalam pengelolaan dana desa. Moralitas merupakan suatu hal penting yang dapat mempengaruhi perilaku seorang individu. Salah satu teori yang dapat digunakan untuk mengobservasi dasar individu dalam melakukan tindakan adalah teory fraud triangel. Salah satu aspek yang terdapat pada teori ini adalah rasioanlisasi. Rasioanlisasi adalah sikap karakter atau serangkaian nilai nilai etis yang memperbolehkan manajemen atau pegawai melakukan tindakan yang tidak jujur.

\section{SIMPULAN DAN SARAN}

Berdasarkan hasil uji analisis data maka Berdasarkan hasil analisis dan pembahasan yang dilakukan yaitu determinan kecurangan akuntansi dalam pengelolaan dana desa, maka dapat diambil kesimpulan sebagai berikut:

1. Asimetri informasi berpengaruh positif signifikan terhadap kecurangan akuntansi dalam pengelolaan dana desa. Ini karena semakin tinggi asimetri informasi administrator dan pengguna, semakin besar kemungkinan terjadinya penipuan.

2. Komitmen organisasi tidak mempengaruhi kecurangan akuntansi dalam pengelolaan dana desa. Hal ini menunjukkan bahwa ada tidaknya komitmen organisasi dalam organisasi tidak mempengaruhi kecurangan seseorang.

3. Kesesuaian kompensasi tidak mempengaruhi kecurangan akuntansi dalam pengelolaan dana desa. Ini membuktikan bahwa pemberian promosi, kompensasi, atau bonus yang layak kepada aparat desa tidak akan berpengaruh jika seseorang melakukan penipuan.

4. Pengendalian intern tidak mempengaruhi kecurangan akuntansi dalam pengelolaan dana desa. Hal tersebut membuktikan bahwa ada atau tidak adanya pengendalian internal tidak mempengaruhi orang yang melakukan kecurangan.

5. Moralitas individu berpengaruh negatif signifikan terhadap kecurangan akuntansi dalam pengelolaan dana desa. Hal ini menunjukkan bahwa individu masih enggan melakukan kecurangan, walaupun pengendalian internal organisasi lemah, jika individu tersebut memiliki tingkat moral yang tinggi atau baik dan berkepribadian jujur.

\section{DAFTAR PUSTAKA}

Adinda, Y. M., dan Ikhsan, S. (2015). Faktor Yang Mempengaruhi Terjadinya Kecurangan (Fraud) di Sektor Pemerintahan Kabupaten Klaten. Accounting Analysis Journal, Vol. 4(3), h. 1-9.

AICPA, SAS No. 99.2002. "Consideration of Fraud in a Financial Statement Audit, AICPA". New York.

Alatas. 1987. Korupsi Sifat Dan Fungsi. Jakarta : LP3ES

Albercht, W. Steve, Chad O. Albercht, Conan C. Albercht, Mark F. Zimbelman. 2011. Fraud Examination. Mason: Cengage Learning.

Albrecht et al. 2012. Fraud Examination. Thrid Edition. South Western. A part of Chengange Learning. USA.

Amrizal. 2004. Pencegahan dan Pendektesian Kecurangan oleh Internal Auditor. Jakarta.

Arfan, Ikhsan dan Muhammad Ishak. 2005. Akuntansi Keprilakuan. Salemba Empat. Jakarta.

Atmadja, Anantawikram Tungga dan Komang Adi Kurniawan Saputra. 2017. Pencegahan Fraud dalam Pengelolaan Keuangan Desa. Jurnal Ilmiah Akuntansi dan Bisnis Volume 12, Nomor 1. Jurnal Ilmiah Akuntansi dan Bisnis. Universitas Pendidikan Ganesha: Bali. Ayuningtyas, Harvita Yulian, dan Sugeng Pamudji. 2012. "Pengaruh Pengalaman Kerja, Independensi, Obyektifitas, Integritas Dan 
Kompetensi Terhadap Kualitas Hasil Audit" Diponegoro Journal Of Accounting, Vol. 1 No.2.

COSO. 2004. Enterprise Risk ManagementIntegrated Framework. The Committee Of Sponsoring Organizations Of The Treadway Commission.

Dellaportas, S. 2013. Conversations with inmate accountants: Motivation, opportunity and the fraud triangle. Accounting Forum 37 (2013) 29-39.

Firdaus. 2018. Analisis Faktor-Faktor Yang Mempengaruhi Kecenderungan Pegawai Melakukan Kecurangan/Fraud Pada Sektor Pemerintahan (Studi Kasus Pada Pemerintahan Di Kabupaten Klaten). Jurnal UII: Yogyakarta.

Green, Stephen G. And Terence R. Mitchell.1979. "Attributional Processes of Leaders in Leader-Member Interactions", dalam Organizational Behavior and Human Perfomance.

Ghozali, Imam. (2011). Aplikasi Multivariate dengan Program IBM SPSS 19 (edisi kelima). Semarang: Badan Penerbit Universitas Diponegoro.

Heider, Fritz. 1958. ThePpsychology of Interpersonal Relations, New York: Wiley

IAI.2001.Standar Profesional Akuntan Publik.Jakarta:Salemba Empat.

Indonesia Corruption Watch (ICW). 20152017.Jumlah Kasus Korupsi. ICW, Jakarta.

Kelley, Harold H. (1967). Attribution Theory in Social Psychology. Nebraska Symposium on Motivation, Vol 15, 1967, 192-238.

Kyalo, Shadrack Maweu, Aquilars M. Kalio, and Solomon Ngahu. "Role of Fraud

Prevention in Enhancing Effective Financial Reporting in County Governments in Kenya: Case of Nakuru County, Kenya."

Lin, et al. 2006. The Effect of Ausit Committee Performance on Earnings Quality. Mangerial Auditing Journal, 21 (9).

Mulyadi. 2008. Sistem Akuntansi. Jakarta: Salemba Empat.

Mulyadi dan Kanaka Puradiredja. 2010. Auditing, Edisi Kelima. Salemba Empat. Jakarta.

Nurul et al .2017. Accounting Fraud: Determinant, Moderation Of Internal Control System And The Implication To Financial Accountability . International Conference and Call for Papers. Jember.

Norbarani, Listiana. 2012. "Pendeteksian Kecurangan Laporan Keuangan Dengan
Analisis Fraud Triangle yang Diadopsi Dalam SAS NO.99". Fakultas Ekonomika dan Bisnis Universitas Diponegoro.

Permatasari, D., Kurrohman, T., \& Kartika. (2017). Analisis Faktor-Faktor yang Mempengaruhi Terjadinya Kecenderungan Kecurangan (Fraud) di Sektor Pemerintah (Studi pada Pegawai Keuangan Pemerintah Kabupaten Banyuwangi. Jurnal Keuangan Dan Perbankan, 14(1), 37-44.

Peraturan Pemerintah Republik Indonesia Nomor 60 Tahun 2008 tentang Sistem Pengendalian Internal Pemerintah.

Peraturan Presiden Nomor 11 Tahun 2015 Tentang Kementerian Dalam Negeri;

Peraturan Pemerintah Nomor 43 Tahun 2014 Tentang Peraturan Pelaksanaan UU Nomor 6 Tahun 2014 Tentang Desa

Peraturan Pemerintah Nomor 60 Tahun 2014 Tentang Dana Desa Yang Bersumber Dari APBN.

Peraturan Presiden Nomor 12 Tahun 2015 Tentang Kementerian Desa, Pembangunan Daerah Tertinggal Dan Transmigrasi.

Peraturan Pemerintah Dalam Negeri Nomor 113 Tahun 2014 Tentang Pengelolaan Dana Desa

Ratmono. (2014). Can Fraud Triangle detect the fraud?. Universitas Diponegoro.

Singleton, T, et al. 2006. Fraud Auditing and Forensic Accounting, Third Edition. New Jersey : Wiley.

Spillane, James J. (2003). Pariwisata dan Wisata Budaya, CV. Rajawali.

Sugiyono. (2007). Statistika untuk Penelitian. (E. Mulyatinignsih, Ed.). Jawa Barat: CV ALFABETA

Susanto,Azha. 2013. Sistem Informasi Akuntansi. Cetakan Pertama Bandung: Lingga Jaya.

Steers, M. Richard. 1985. Efektifitas Organisasi. Jakarta: Erlangga. Syahrina, D., Irianto, G., \& UU No 33

UU No 6 Tahun 2014 tetang Desa

Undang-undang Nomor 32 Tahun (2004) Tentang Pemerintah Daerah

Undang-undang Nomor 22 Tahun (1999) Tentang Pemerintah Daerah

Undang-undang Nomor 25 Tahun (1999) Tentang Perimbangan Keuangan Antara Pemerintah Pusat dan Pemerintah Daerah

Undang-undang Nomor 31 Tahun (1999) Tentang Pemberantasan Tindak Pidana Korupsi

Undang-undang Nomor 10 Tahun (2004) Tentang Pembentukan Peraturan Daerah.

Vona, Leonard W. 2008. Fraud Risk Assessment 
Determinan Kecurangan Akuntansi dalam Pengelolaan Dana Desa Abdul Hadi, Ikhsan Budi Raharjo, Wahidahwati

Building A Fraud Audit Program. New Jersey: John Wiley \& Sons, Inc.

Yanita. 2015. Faktor Yang Mempengaruhi Terjadinya Kecurangan (Fraud) Di Sektor Pemerintahan Kabupaten Klaten. Jurnal
Akuntansi Dan Pendidikan. UNNES.

Waworuntu, Bob. 2003. Determinan Kepemimpinan. Makalah Sosial Humaniora, vol.7, no. 2, Desember 2003. 